\title{
Athies-sous-Laon - Uchery
}

$n^{\circ} 9320$

\section{Bruno Robert}

\section{OpenEdition}

\section{Journals}

Édition électronique

URL : https://journals.openedition.org/adlfi/5576

ISSN : 2114-0502

Éditeur

Ministère de la Culture

Référence électronique

Bruno Robert, «Athies-sous-Laon - Uchery » [notice archéologique], ADLFI. Archéologie de la France Informations [En ligne], Hauts-de-France, mis en ligne le 01 mars 2007, consulté le 21 septembre 2021. URL : http://journals.openedition.org/adlfi/5576

Ce document a été généré automatiquement le 21 septembre 2021.

(c) ministère de la Culture et de la Communication, CNRS 


\section{Athies-sous-Laon - Uchery}

$n^{\circ} 9320$

Bruno Robert

Opération négative

1 Ce diagnostic réalisé les 11 et 12 décembre 2007 sur une surface de $12937 \mathrm{~m}^{2}$ dans un environnement riche en vestiges historiques (dont certains de l'époque romaine) c'est avéré totalement négatif.

INDEX

Index chronologique : Empire romain

Index géographique : Picardie, Aisne (02), Athies-sous-Laon

operation Expertise (EX)

\section{AUTEURS}

BRUNO ROBERT

Inrap 